\title{
Growth and Fate of PSA-NCAM+ Precursors of the Postnatal Brain
}

\author{
Tamir Ben-Hur, ${ }^{1}$ Bernard Rogister, ${ }^{1}$ Kerren Murray, ${ }^{1}$ Geneviève Rougon,, ${ }^{2}$ and Monique Dubois-Dalcq ${ }^{1}$ \\ 1 Unite de Neurovirologie et Régénération du Système Nerveux, Institut Pasteur, 75724 Paris, France, and \\ 2Institut de Biologie du Développement de Marseille, Marseille 13288, France
}

Oligodendrocyte-type 2 astrocyte (O-2A) lineage cells are derived from multipotential stem cells of the developing CNS. Precursors of $\mathrm{O}-2 \mathrm{~A}$ progenitors express the polysialylated (PSA) form of the neural cell adhesion molecule (NCAM) and are detected in neonatal rat brain glial cultures. It is unclear how such PSA-NCAM + "pre-progenitors" are related to neural stem cells and whether they still have the potential to differentiate along several neural lineages. Here we isolated PSA-NCAM+ pre-progenitor cells from glial cultures by immunopanning and found that most of these cells expressed nestin and PDGFreceptor- $\alpha$ but not O-2A antigens. PSA-NCAM+ cells synthesized transcripts for fibroblast growth factor (FGF) receptors 1 , 2 , and 3 and responded to FGF2 by survival and proliferation, growing into large clusters resembling neural spheres. FGF2induced proliferation of PSA-NCAM+ pre-progenitors was significantly enhanced by thyroid hormone (T3), which on its own did not increase cell survival or mitosis. After adhesion and withdrawal of the mitogen, spheres generated mostly oligodendrocytes and astrocytes but very rarely neurons. PSA-NCAM immunopanned cells grown in epidermal growth factor (EGF) also adopted a mostly glial fate after differentiation. In contrast, PSA-NCAM-negative cells and striatal neonatal stem cells, grown in EGF or FGF2, generated the three CNS cell types. Like neural stem cells, PSA-negative cells generated more oligodendrocytes and fewer neurons when expanded in FGF2 and T3. Thus emergence of PSA-NCAM at the surface of neonatal brain precursors coincides with their restriction to a glial fate. T3 modulates these events by enhancing PSA-NCAM+ preprogenitor growth in FGF2 and favoring an oligodendrocyte fate.

Key words: oligodendrocyte precursors; newborn rat brain; polysialylated form of NCAM; glial fate; astrocytes; thyroid hormone
The three major CNS cell types emerge on a precise time schedule from proliferating neuroepithelial cells in the ventricular zone during embryonic and neonatal development. Multipotential neural stem cells can be isolated from CNS starting at embryonic day 12 until adulthood (Williams et al., 1991; Reynolds and Weiss, 1992; Davis and Temple, 1994; Gritti et al., 1996; Johe et al., 1996). In the newborn rodent CNS, most neurons have already been generated, whereas glial progenitors are actively proliferating. Whether oligodendrocytes and astrocytes emerge at this stage from a common glial precursor or from distinct precursor cells is being actively investigated (Price, 1994; Goldman, 1996). The most extensively studied glial precursor is the oligodendrocyte-type 2 astrocyte (O-2A) progenitor isolated from neonatal optic nerve (Raff et al., 1983; Raff, 1989). This bipolar cell expresses membrane gangliosides such as GD3 (Goldman et al., 1984) and those recognized by the monoclonal antibody A2B5 (Eisenbarth et al., 1979; Raff et al., 1983). Type 2 astrocytes express glial fibrillary acidic protein (GFAP) as well as gangliosides characteristic of these progenitors but are rarely

\footnotetext{
Received April 9, 1998; accepted May 15, 1998.

This work has been supported by a long-term fellowship from the International Human Frontiers in Science Program Organization (T.B.-H.) and the Association de Recherche sur le Cancer and the Association Française contre les Myopathies (G.R.). B.R. is a senior research associate of the Belgian National Fund for Scientific Research. We thank Drs. J. Goldman, I. Sommer, R. McKay, and K. Heldin for the generous gifts of antibodies, and Dr. R. Bruzzone for critical reading of this manuscript.

Dr. Ben-Hur's present address: Department of Neurology, Hebrew University, Hadassah Medical School, P.O. Box 12000, Jerusalem 91120, Israel.

Correspondence should be addressed to Dr. Monique Dubois-Dalcq, Unite de Neurovirologie et Régénération du Système Nerveux, Institut Pasteur, 25, Rue du Dr. Roux, 75724 Paris, Cedex 15, France.

Copyright (C) 1998 Society for Neuroscience $\quad 0270-6474 / 98 / 185777-12 \$ 05.00 / 0$
}

encountered during CNS development in vivo. Type 1 astrocytes are characterized in vitro by a GFAP +, A2B5- antigenic phenotype, and they originate from immature astroblasts arising from the subventricular zone during late embryonic and early postnatal periods (for review, see Goldman, 1996).

Development of the O-2A lineage is controlled by growth factors and hormones acting via membrane-associated and nuclear receptors. O-2A proliferation and migration can be mediated by platelet-derived growth factor (PDGF) in vitro (Raff et al., 1988; Richardson et al., 1988; Armstrong et al., 1990). Basic fibroblast growth factor (FGF2) is also mitogenic for O-2A progenitors alone or in synergism with PDGF, blocking their differentiation into oligodendrocytes (Bogler et al., 1990; McKinnon et al., 1990). As O-2A progenitors mature, they become multipolar and start to express sulfatide and other membrane-associated antigens that are recognized by the monoclonal antibody $\mathrm{O} 4$ (Sommer and Shachner, 1981; Bansal et al., 1989; for review, see Pfeiffer et al., 1994). Thyroid hormone limits the number of O-2A cell divisions and allows them to enter the differentiation stage (Barres et al., 1994). This hormone also promotes myelination and synthesis of the myelin proteolipid protein and basic protein in oligodendrocytes (Almazan et al., 1985; Farsetti et al., 1991; Baas et al., 1997).

To determine whether neural stem cells generate bipotential or distinct unipotential glial precursors, we characterized the stage of development between multipotential, self-renewing stem cells and committed O-2A progenitors. Precursors of O-2A cells have been identified in neonatal rat primary glial cultures and were shown to generate O-2A progenitors (Grinspan et al., 1990; Hardy and Reynolds, 1991). These small, round, proliferating 
"pre-progenitor" cells are responsive to PDGF and express the embryonic polysialylated form of the neural cell adhesion molecule (PSA-NCAM) before O-2A progenitor antigens emerge (Grinspan and Franceschini, 1995). In this study, we have further characterized these pre-progenitor cells that proliferated and formed cell clusters or spheres in response to FGF2 or EGF. These cells expressed both FGF and thyroid receptor genes (THRs), and addition of T3, the active form of thyroid hormone, enhanced the mitogenic effect of FGF2. We then compared the fate of these neonatal PSA-NCAM+ precursors to that of striatal neural stem cells and to PSA-NCAM negative precursors expanded with EGF or FGF2 in neurospheres (Weiss et al., 1996). After adhesion, PSA-NCAM+ clusters generated almost exclusively cells of the oligodendrocyte lineage and astrocytes, whereas the other precursors or stem cells were multipotential, giving rise to neurons, astrocytes, and oligodendrocytes. Thus emergence of PSA-NCAM at the surface of neonatal brain precursors coincides with their restriction to a mostly glial fate. T3 modulates these events by enhancing PSA-NCAM+ pre-progenitor growth in FGF2 and favoring an oligodendrocyte fate.

\section{MATERIALS AND METHODS}

Preparation of mixed glial cultures. Sprague Dawley newborn rats were anesthetized by hypothermia and then killed by rapid decapitation. The cerebral hemispheres, including deep nuclei, white matter, and subventricular zones, were isolated, and the cerebellum and brainstem were discarded. After removal of meninges, the tissue was minced, digested in $0.025 \%$ Trypsin for $20 \mathrm{~min}$, and mechanically dissociated with a $5 \mathrm{ml}$ pipette to obtain a single-cell suspension. Debris were removed by centrif ugation through a 4\% BSA (Sigma, Paris, France) layer. The cells were suspended in DMEM supplemented with 5\% FCS (both from Life Technologies, Eragny, France) and plated onto T-75 flasks (Costar, Badhoeverdorp, The Netherlands), coated with $10 \mu \mathrm{g} / \mathrm{ml}$ poly-D-lysine (Sigma) at a density of $3.5-4 \times 10^{7}$ cells/flask.

Isolation and culture of PSA-NCAM-positive and PSA-NCAM-negative cells. Oligodendrocyte lineage cells were enriched from mixed glial cultures by the shaking method before PSA-NCAM+ cells were isolated by immunopanning (Grinspan and Franceschini, 1995). Briefly, $100 \mathrm{~mm}$ Falcon Optilux Petri dishes were first coated with secondary antibody (goat anti-mouse IgM, $\mu$-chain specific, Chemicon, Temecula, CA) at 5 $\mu \mathrm{g} / \mathrm{ml}$ in $50 \mathrm{~mm}$ Tris- $\mathrm{HCl}, \mathrm{pH} 9.5$, for $18 \mathrm{hr}$ at $4^{\circ} \mathrm{C}$. The plates were then washed three times in PBS and coated with anti-PSA-NCAM antibody [anti-Men-B antibody (Rougon et al., 1986)] at 1:250 dilution in PBS with $0.2 \% \mathrm{BSA}$ at room temperature for at least $1 \mathrm{hr}$.

After $2-3 \mathrm{~d}$ in vitro, the T-75 flasks containing the primary brain cells were placed on a rotary shaker at $37^{\circ} \mathrm{C}$ for $30 \mathrm{~min}$ at $140 \mathrm{rpm}$ in the presence of $5 \mathrm{~mm}$ L-leucine methyl ester (Sigma) to eliminate the microglia. The medium was then replaced and equilibrated with $\mathrm{CO}_{2}$, and the flasks were shaken overnight at $200 \mathrm{rpm}$. Detached cells were plated on tissue culture dishes for $30 \mathrm{~min}$ to allow attachment of residual microglia and astrocytes. The floating cells were then collected and plated at $5 \times$ $10^{6}$ cells $/ 100 \mathrm{~mm}$ dish coated for PSA-immunopanning and allowed to bind at $37^{\circ} \mathrm{C}$ for $30 \mathrm{~min}$. In the majority of experiments, nonadherent cells were washed off extensively before the adherent, PSA-NCAM+ cells were removed by trypsinization, washed three times, and resuspended in serum-free, modified N2 medium (see below). Cell viability after shaking and immunopanning was $\geq 90 \%$ by trypan blue exclusion test. In some experiments, nonadherent cells that were not adhering to the anti-PSA antibody-coated dish were collected, centrifuged $(400 \times g$, $8 \mathrm{~min}$ at room temperature), and then washed three times to remove any of the remaining FCS. These were also resuspended in a serum-free, modified N2 medium,.

PSA-NCAM-positive or -negative cells were then plated on $35 \mathrm{~mm}$ tissue culture dishes (Falcon, Le Pont-de Claix, France), Labtek multiwell (Nunc, Life Technologies, Eragny, France), or in 96-well plates (Costar, Cambridge, MA) at a density of $30 \times 10^{3}$ cells $/ \mathrm{cm}^{2}$. Modified $\mathrm{N} 2$ medium consisted of DMEM, $5 \mathrm{mg} \%$ human apo-transferrin, $1 \mathrm{~mm}$ sodium pyruvate, $0.05 \% \mathrm{BSA}, 10 \mathrm{ng} / \mathrm{ml}$ D-biotin, $30 \mathrm{~nm}$ sodium selenite, $10 \mathrm{~nm}$ hydrocortisone, $15 \mathrm{~nm}$ triiodo-L-thyronine (T3), $5 \mu \mathrm{g} / \mathrm{ml}$ of bovine insulin, and $25 \mu \mathrm{g} / \mathrm{ml}$ of gentamycin. In some experiments (as detailed in the text), T3 was omitted from the medium. DMEM and sodium pyru-

\begin{tabular}{|c|c|c|}
\hline & $\begin{array}{l}\% \text { of total cells } \\
(\text { mean } \pm \text { SEM) }\end{array}$ & $\begin{array}{l}\% \text { of PSA-NCAM+ } \\
\text { cells }^{a}(\text { mean } \pm \text { SEM })\end{array}$ \\
\hline $\begin{array}{l}\text { PSA-NCAM } \\
\qquad(\mathrm{n}=14 \text { experiments })\end{array}$ & $87.0 \pm 4$ & \\
\hline GD3 $(\mathrm{n}=8)$ & $15.0 \pm 8$ & $14.2 \pm 8.4$ \\
\hline $\mathrm{A} 2 \mathrm{~B} 5(\mathrm{n}=3)$ & $11.7 \pm 2$ & $-^{b}$ \\
\hline $\mathrm{O} 4(\mathrm{n}=10)$ & $7.9 \pm 5.4$ & $-^{b}$ \\
\hline $\operatorname{GFAP}(\mathrm{n}=10)$ & $2.9 \pm 1.4$ & $1.9 \pm 1.2$ \\
\hline Nestin $(\mathrm{n}=7)$ & $80.6 \pm 6$ & $85.4 \pm 6.7$ \\
\hline $\operatorname{PDGFR} \alpha(\mathrm{n}=4)$ & $93.2 \pm 4.6$ & $96.2 \pm 3.7$ \\
\hline $\begin{array}{l}\text { MAP2b (clone AP20) } \\
\quad(\mathrm{n}=5)\end{array}$ & $2.6 \pm 1.7$ & $3.5 \pm 1.9$ \\
\hline $\begin{array}{l}\text { MAP2abc (clone HM-2) } \\
\quad(\mathrm{n}=3)\end{array}$ & $80.3 \pm 12.9$ & ND \\
\hline
\end{tabular}

ND, not determined.

${ }^{a}$ By double or triple labeling of panned cells with anti PSA-NCAM antibody and antibodies to the other antigens listed.

${ }^{b}$ The percentage of $\mathrm{O} 4+$ or A2B5 + cells from PSA-NCAM+cells could not be determined because all three antibodies are of mouse IgM class. However, most O4+ cells did not express nestin and therefore probably do not bear PSA-NCAM on their surface.

vate were from Life Technologies and all other factors from Sigma. In various experiments, $10 \mathrm{ng} / \mathrm{ml}$ (or other concentrations if specifically mentioned) human FGF2, human EGF, or PDGF-AB (those three factors were a generous gift of Amgen, Thousand Oaks, Ca) were added.

Isolation and culture of newborn striatum neural stem cells. One-day-old Sprague Dawley newborn rats were anesthetized and rapidly killed by cervical transection. Cerebral hemispheres, freed of meninges, were placed in an HBSS solution, and striata including subependyma were dissected out. Tissue was minced with a scalpel blade, transferred in DMEM/F12 (1:1, v/v; Life Technology), and triturated by passing through a fire-polished Pasteur pipette. The cell suspension was then filtered through a $70 \mu \mathrm{m}$ nylon mesh, and $10^{6}$ viable cells were plated in $20 \mathrm{ml}$ of medium in an uncoated T25 tissue culture flask (Costar). The culture medium consisted of DMEM/F12 supplemented with B27 (Life Technology), $25 \mu \mathrm{g} / \mathrm{ml}$ of bovine insulin, $100 \mu \mathrm{g} / \mathrm{ml}$ of transferrin, $20 \mathrm{~nm}$ progesterone, $60 \mu \mathrm{M}$ putrescin, $30 \mathrm{~nm}$ sodium selenite, and $20 \mathrm{ng} / \mathrm{ml}$ of EGF or $10 \mathrm{ng} / \mathrm{ml}$ of FGF2. In some cases, $15 \mathrm{~nm} \mathrm{T3}$ was added. Every $3 \mathrm{~d}$, half of the medium was renewed. After 1 week, numerous spheres had grown in these conditions.

Adhesion of spheres or clusters. Striata neural stem cell clusters were transferred by pipetting onto polyornithine-coated $35 \mathrm{~mm}$ dishes at low density (polyornithine was from Sigma and used at $100 \mu \mathrm{g} / \mathrm{ml}$ ). The culture medium remained unchanged except that EGF or bFGF was omitted, and after 3-5 d, cultures were formaldehyde-fixed and processed for immunocytofluorescence.

PSA-NCAM-positive and -negative clusters and spheres that were grown for 2 weeks on uncoated dishes in defined medium supplemented with FGF2 and T3 were collected by gentle pipetting and transferred to polyornithine-coated dishes or coverslips at low density to determine the fate of cells derived from individual clusters. At that time, FGF2 was omitted from the medium to allow differentiation (McKinnon et al., 1990).

Immunocytochemistry. Antibodies included mouse IgG anti-GD3 [gift of J. Goldman (Columbia University Medical School) (Goldman et al., 1984); 1:200 dilution], A2B5 mouse IgM (Boehringer Mannheim, Indianapolis, IN; 1:100 dilution), O4 mouse IgM [gift of I. Sommer (Max Delbrück Center for Molecular Medicine) (Sommer and Schachner, 1981; 1:15 dilution], rabbit anti-GFAP (Chemicon; 1:200 dilution), rabbit anti-nestin [gift from R. McKay (NINDS, NIH) (Hockfield and McKay, 1985); 1:200 dilution], rabbit anti-PDGF receptor- $\alpha$ (PDGFR $\alpha$ ) [gift from K. Heldin, Ludwig Institute for Cancer Research (Nishiyama et al., 1996); 1:500 dilution], and mouse IgG1 anti-MAP2 [clone AP20, recognizing $\mathrm{a}$ and $\mathrm{b}$ isoforms (Boehringer), 1:100 dilution; and clone HM-2, recognizing $\mathrm{a}, \mathrm{b}$, and $\mathrm{c}$ isoforms (Sigma), 1:100 dilution].

Live or fixed cells were incubated with primary antibodies (Abs) against surface antigens for $30 \mathrm{~min}$ at $4^{\circ} \mathrm{C}$, rinsed three times with PBS, 


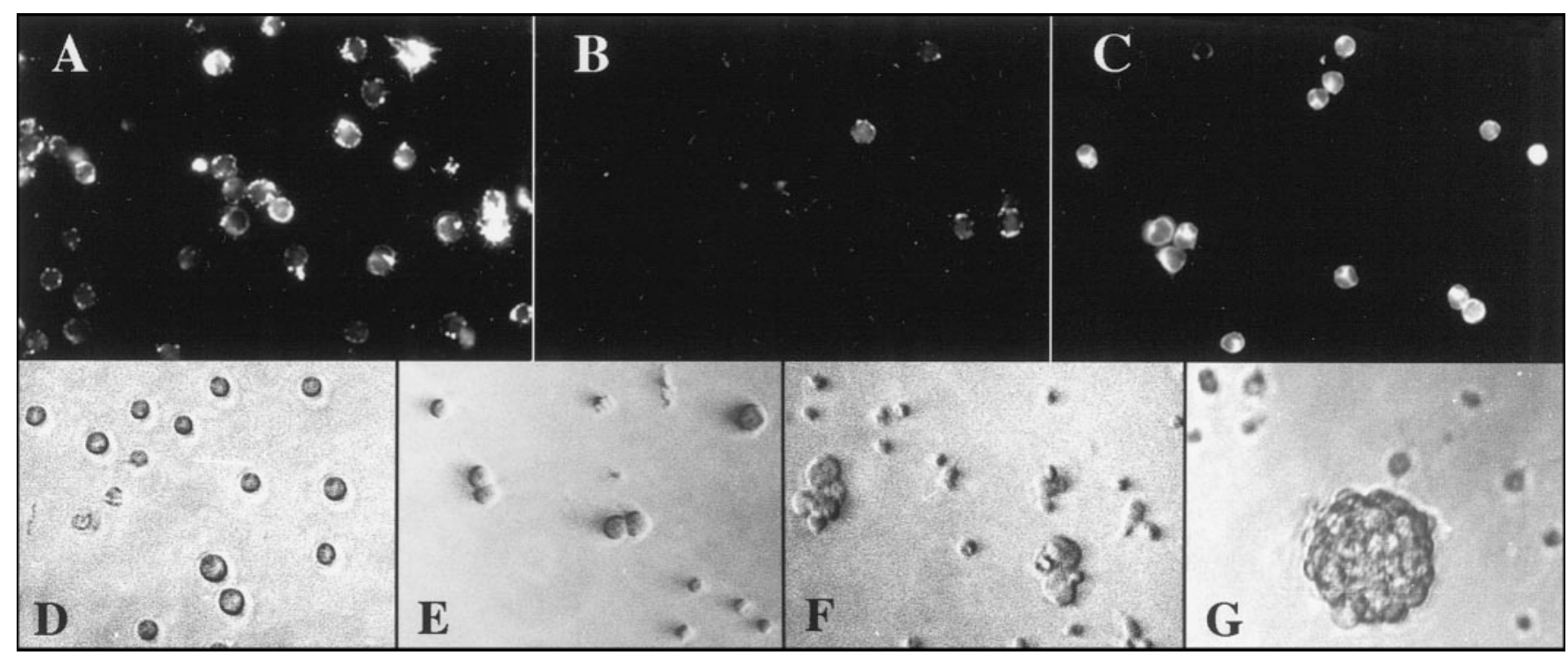

Figure 1. $A-C$, Immunofluorescence staining of neonatal neural precursors immediately after immunopanning. $A$, Of the cells identified by phase microscopy in this microscopic field, 32 of $36(89 \%)$ are PSA-NCAM.$+ B$, Only four cells $(11 \%)$ in the same field are GD3+. $C$, In this other field, 13 of 15 cells are positive with clone HM-2 anti-MAP2, which detects MAP2abc isoforms. $D-G$, Phase micrographs showing progressive growth of PSA-NCAM+ immunopanned cells into clusters on a nonadherent surface, during the first week in culture with FGF2. $D$, The cells at plating day are separated into single cells: $E$, after $1 \mathrm{~d}$, some cells have divided; $F$, after $3 \mathrm{~d}$, there are small cell clusters; $G$, after 1 week, larger cell clusters are observed.

and then exposed to appropriate rhodamine- or fluorescein-conjugated secondary $\mathrm{Ab}$ for $30 \mathrm{~min}$ at $4^{\circ} \mathrm{C}$. After PBS washes they were fixed and permeabilized in $4 \%$ formaldehyde and $0.1 \%$ Triton $\mathrm{X}-100$ for $15 \mathrm{~min}$ (in cases where cytoskeleton components were detected, the cells already fixed in formaldehyde were fixed again and permeabilized for $10 \mathrm{~min}$ at $-20{ }^{\circ} \mathrm{C}$ in $5 \%$ acetic acid $/ 95 \%$ ethanol). The cultures were then incubated with primary Abs against cytoplasmic antigens for $30 \mathrm{~min}$ at room temperature, washed, and exposed to AMCA-conjugated (and/or fluorescein-conjugated, if not used for surface antigen) secondary Ab. Triple immunofluorescence was made possible by using primary Abs of mouse IgM and IgG classes and a rabbit $\mathrm{Ab}$. Rhodamine-conjugated goat anti-mouse IgM (Jackson ImmunoResearch, West Grove, PA; $\mu$-chain specific, no cross-reaction with $\mathrm{IgG}, 1: 100$ dilution) was used to detect mouse IgM (anti-PSA-NCAM, A2B5, and O4 Ab). Biotin-labeled goat anti-mouse IgG (Jackson; $\mathrm{F}_{\mathrm{C} \gamma}$ fragment specific, no cross-reaction with mouse IgM, 1:100 dilution), followed by fluorescein-streptavidin (Vector, Burlingame, CA, 1:200), was used to detect GD3 and both antiMAP2 monoclonal antibodies. Fluorescein-conjugated goat anti-rabbit IgG (Jackson; no cross-reaction with mouse Ig, 1:200 dilution) was used to detect nestin and PDGFR $\alpha$. 7-Amino-4-methylcoumarin-3-acetic acid fluorophore-conjugated donkey anti-rabbit IgG (Jackson; no crossreaction with mouse Ig, 1:100 dilution) was used to detect GFAP. For each preparation of cells, immunopanned cells were plated as a centered drop on $35 \mathrm{~mm}$ coated dishes to attach for 1-2 hr and then stained with PSA-NCAM Abs (1:200 dilution) combined with other Abs to enable quantification of percentage of positive cells from total and from PSA$\mathrm{NCAM}+$ cells. Clusters that were grown in Labtek wells were washed very gently because they were loosely attached to the surface.

For identification of the different CNS cell type in differentiated clusters, three triple-labeling combinations were used: (1) O4 for oligodendrocyte lineage cells (visualized with rhodamine), MAP2 for neurons (clone AP-20, fluorescein) and GFAP for astrocytes (AMCA); and (2) A2B5 for O-2A progenitors and type 2 astrocytes (rhodamine), GD3 for O-2A cells (fluorescein) and GFAP for astrocytes (AMCA). The counting was performed blind. In the neural stem cells experiments (see Fig. 6), at least 300 cells per plate were counted in random fields. In the experiments with PSA-NCAM-positive and -negative cells (shown in Fig. 7), all cells that had migrated out of each adherent cluster on the culture dish were counted by scanning all nonoverlapping microscopic fields (to avoid double counting). One-tailed unpaired Student's $t$ tests were performed using InStat 2.01 software (Graphpad software, 1993) or Excell 5.0.

BrdU incorporation. Cell proliferation was quantified by BrdU incorporation index (McKinnon et al., 1990). Cultures were incubated for 16 hr with $10 \mu \mathrm{M}$ BrdU (Sigma) in DMEM. At the end of incubation period the cells were fixed for $10 \mathrm{~min}$ in $95 \%$ ethanol $/ 5 \%$ acetic acid. DNA was denaturated for $10 \mathrm{~min}$ in $2 \mathrm{~N} \mathrm{HCl}$ and then neutralized for $10 \mathrm{~min}$ with $0.1 \mathrm{~N}$ sodium borate, $\mathrm{pH}$ 8.5. Cells were incubated for $30 \mathrm{~min}$ with anti-BrdU antibody (Becton Dickinson, Le Pont-de Claix, France; 1:50 dilution), followed by $30 \mathrm{~min}$ in a fluorescein-conjugated goat anti-mouse IgG antibody (Chemicon; 1:100 dilution). In most experiments, fixed cells were counterstained for $10 \mathrm{~min}$ with $1 \mu \mathrm{g} / \mathrm{ml}$ propidium iodide in $0.1 \%$ sodium citrate buffer to facilitate cell counting by the visualization of cell nuclei. When BrdU labeling was combined with surface labeling, cells were first fixed in $4 \%$ formaldehyde and incubated with PSANCAM antibody (dilution 1:250) for $45 \mathrm{~min}$, followed by washing and incubation with rhodamine-conjugated anti-mouse IgM (dilution 1:100). The clusters were then post-fixed with acid-alcohol and processed for BrdU labeling as described above.

MTT assay. Viable cells and cell clusters were identified in situ and then quantified colorimetrically by the MTT assay. MTT is a tetrazolium salt that is cleaved in mitochondria of metabolically active cells to form a formazan dye. MTT $(5 \mu \mathrm{g} / \mathrm{ml}$; Boehringer) was added to cultures grown in 96-well plates and incubated for $4 \mathrm{hr}$ in $37^{\circ} \mathrm{C}$. Cultures were then visualized under an inverted microscope to count single cells or clusters of approximately three cells that contained MTT + cells in seven random fields/well. The cultures were then incubated overnight in solubilization solution (10\% SDS, $10 \mathrm{~mm} \mathrm{HCl}$, added in 1:1 ratio). Spectrophotometrical absorbance was measured in $550 \mathrm{~nm}$ using an ELISA reader.

Terminal deoxynucleotidyl transferase (TdT)-mediated biotinylated UTP nick end labeling (TUNEL) assay. DNA fragmentation characteristic of cell death by apoptosis was detected in situ by the TUNEL method [Gavrieli et al., 1992 (Boehringer Mannheim kit)]. Briefly, fixed cells (4\% formaldehyde) were permeabilized for 2 min with $0.1 \%$ Triton X-100 in sodium citrate buffer, washed twice, and then incubated for $1 \mathrm{hr}$ in $37^{\circ} \mathrm{C}$ with TdT and fluorescein-labeled nucleotides. DNase-treated cultures served as positive controls, and cultures that were incubated without TdT served as negative controls.

$R T-P C R$. Total cellular RNA was extracted using the RNeasy Kit from Qiagen (Courtaboeuf, France) and was quantified spectrophotometrically. For reverse transcription, $1 \mu \mathrm{g}$ of total RNA was used in a $20 \mu \mathrm{l}$ reaction containing either $500 \mathrm{ng}$ of oligo(dT) $)_{12-18}$ or $250 \mathrm{ng}$ of random hexamers, 10 mM DTT, dNTP mix (dATP, dCTP, dGTP, dTTP, each at $0.5 \mathrm{mM}$ ), first-strand buffer (Life Technologies), and $200 \mathrm{U}$ of Superscript II reverse transcriptase (Life Technologies). The mixture was incubated for $1 \mathrm{hr}$ at $42^{\circ} \mathrm{C}$. After $15 \mathrm{~min}$ of denaturation at $70^{\circ} \mathrm{C}, 1.5 \mu \mathrm{l}$ of the cDNA was used in a $50 \mu \mathrm{l}$ "hot-start" PCR reaction containing the PCR buffer, appropriate $\mathrm{MgCl}_{2}$ concentration, $250 \mathrm{ng}$ of each primer, $0.2 \mathrm{~mm}$ dNTP 

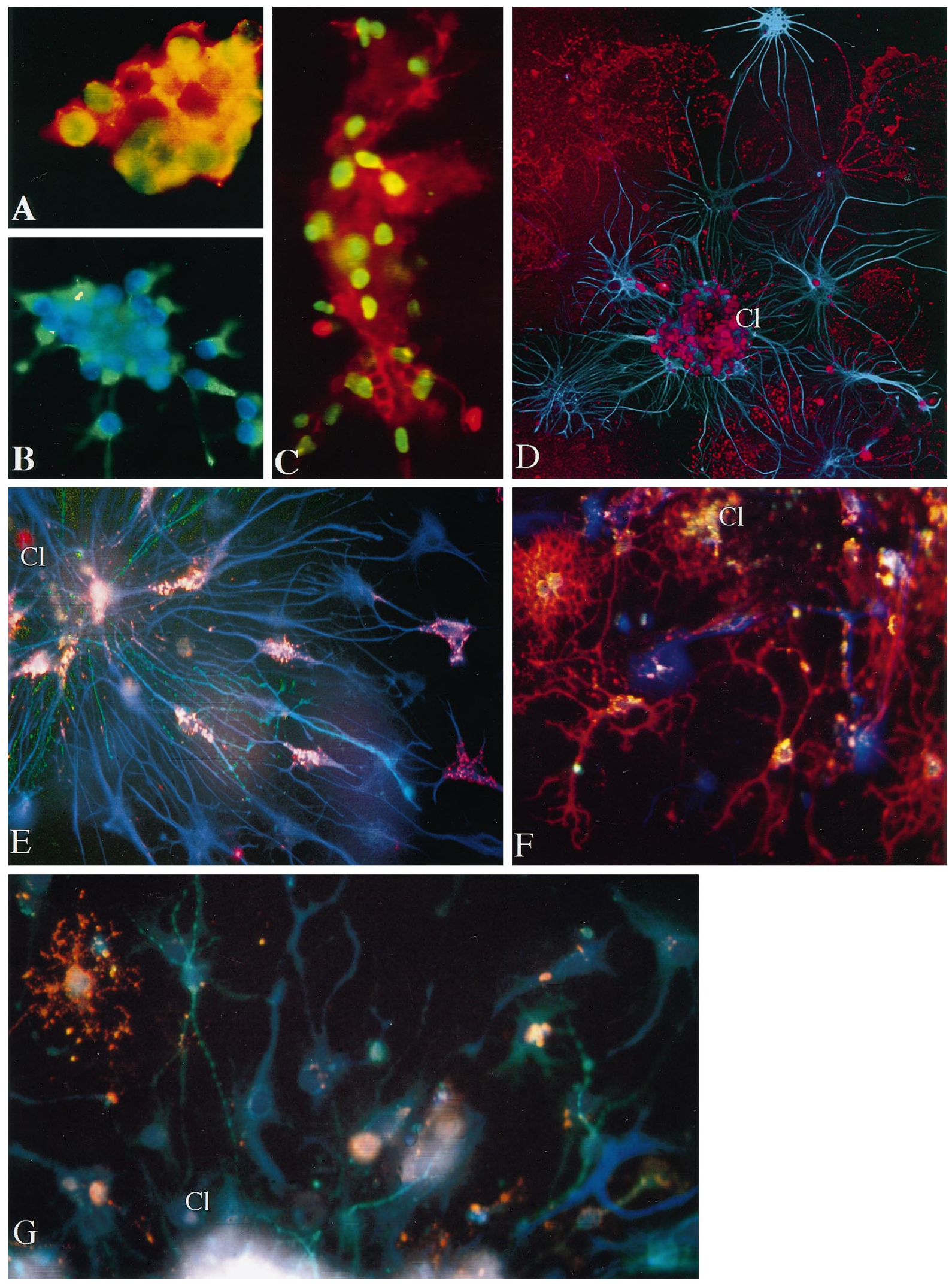

Figure 2. $A-C$, Mitosis and differentiation of neonatal neural precursors grown in EGF and FGF2. A, A typical proliferating cluster of PSA-NCAM+ cells (red) with many BrdU+ nuclei ( green). B, Clusters of cells are nestin + ( green). Nuclei are counterstained with Hoechst (blue). C, EGF expanded clusters also had many PSA-NCAM+ cells $($ red $)$ with BrdU+ nuclei ( green), although a few of these are also associated with PSA-NCAM-negative cells $(l e f t) . D-G$, Migration and differentiation of neural precursors after adhesion were studied after triple labeling for 04/MAP2/GFAP except in $E$. Clusters were attached to glass to perform the staining and are indicated by $C l . D, E$, PSA-NCAM immunopanned cell cluster grown for (Figure legend continues) 

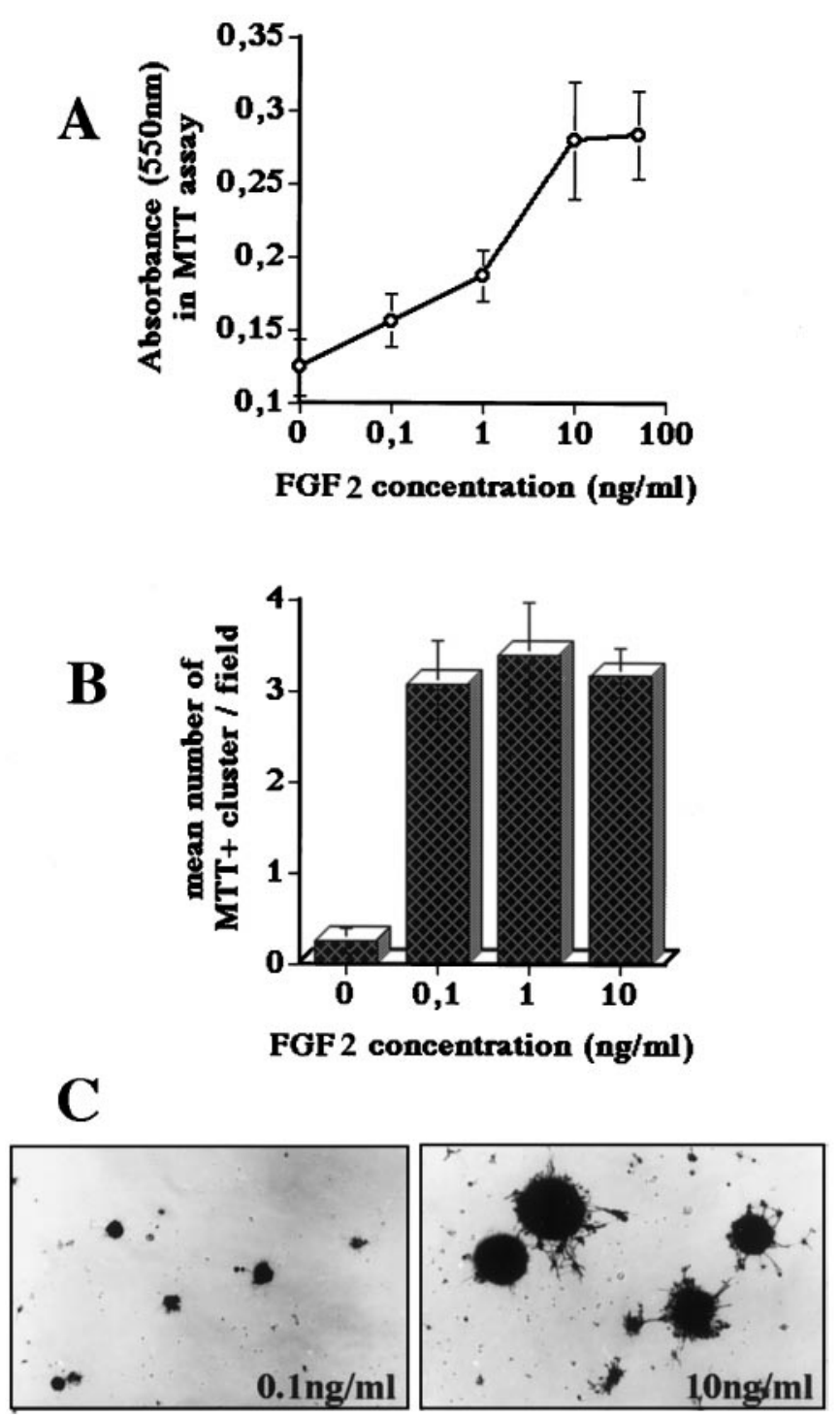

Figure 3. Growth of pre-progenitor clusters, quantified by the MTT assay after 2 weeks in culture. $A$, Dose-response curve with optical density measurements (which represent total number of viable cells at each concentration) shows a dose-dependent increase in the proliferative response between 0.1 and $10 \mathrm{ng} / \mathrm{ml} \mathrm{FGF} 2$ with the response leveling off above $10 \mathrm{ng} / \mathrm{ml} . B$, Counting the number of MTT+ clusters in the tissue culture dish shows that $0.1 \mathrm{ng} / \mathrm{ml}$ FGF2 recruited the same number of cells to grow into cell clusters as $10 \mathrm{ng} / \mathrm{ml}$. $C$, Cell cluster size was much larger with $10 \mathrm{ng} / \mathrm{ml} \mathrm{FGF2} \mathrm{than} \mathrm{with} 0.1 \mathrm{ng} / \mathrm{ml}$.

mix, and $2.5 \mathrm{U}$ of Taq DNA polymerase (Perkin-Elmer, Paris, France). The tube was placed in a Perkin-Elmer 9600 cycler, and 35 cycles $\left(94^{\circ} \mathrm{C}\right.$ for $45 \mathrm{sec}$, appropriate annealing temperature for $45 \mathrm{sec}$ and $72^{\circ} \mathrm{C}$ for 1 min) were followed by a final extension time at $72^{\circ} \mathrm{C}$ for $10 \mathrm{~min}$. Ten microliters of the reaction were electrophoresed on agarose TAE gel and stained with ethidium bromide. The following primers were used with the expected PCR product length in base pair (bp): THR $\alpha 1$ : TGGCCCAAGCTGCTGATGAAGGT (forward), GACTTCCTGATCCTCA AAGA-CCT (reverse), 143 bp; THR $\alpha 2$ : GGAAGACGACAGCAGT GAGGCAAG (forward), GCCT-TGCCTGCCAGGTC-CTCGCA (reverse), 89 bp; THR $\beta 1$ : GGAATGCCAGAGCTGAAGAG (forward), CGTCTGGATCCAGATGGAAT (reverse), 262 bp; THR $\beta 2$ : GG CTGCTGGTGG-TTATTCAT (forward), GTCCAGGCCTGTTCCA GATA (reverse), 319 bp; FGFR1: TGCCG-TATGTCCAGATCC (forward), CTTGTAGATGATGACGGAGC (reverse), 278 bp; FGFR2: AACACCACGGACAAAGAGATT(forward), GTTATCCTCACCAG CGGG(reverse), 392 bp; FGFR3: AGATGCTGAAAGATGATGC GAC (forward), TGCCATCCACTTCACAGGTAG (reverse), 464 bp; FGFR4: CTGTTTCATCAGCATTTGAC (forward), AAATGCC TTGTTCT-TCTGTC (reverse), 482 bp; $\beta$-actin: commercial primers (Stratagene, Montigny-le-Bretonneux, France), 661 bp.

Oligo(dT)-primed cDNA was used for all PCR reactions except for $\operatorname{THR} \beta$, where random hexamers-primed cDNA was amplified. The annealing temperatures were $62^{\circ} \mathrm{C}$ for FGFR primers, $63^{\circ} \mathrm{C}$ for THR $\alpha$ primers, and $57^{\circ} \mathrm{C}$ for $\mathrm{TRH} \beta$ primers. $\mathrm{MgCl}_{2}$ concentration was $1.5 \mathrm{~mm}$ in all cases, except for the THR $\alpha 1$ reaction which contained $2 \mathrm{~mm}$ $\mathrm{MgCl}_{2}$. The identity of the amplified products was checked by digestion with appropriate restriction enzymes. To ensure that observed PCR signals were not caused by amplifying contaminating genomic DNA, control RT-PCR experiments were performed in which cDNA was synthesized without reverse transcriptase.

\section{RESULTS}

\section{Antigenic characterization of PSA-NCAM+ immunopanned cells}

To obtain highly enriched populations of pre-progenitors from the newborn rat brain, PSA-NCAM+ cells were immunopurified from mixed glial cultures established at birth. PSA-NCAM is expressed on most CNS cells at early stages of differentiation, but when mixed glial cultures are set up, most neurons die. Many cells growing on top of the astrocyte layer were expressing PSANCAM. These cells were shaken off and immunopurified with PSA-NCAM antibody 2-3 d after establishment of the neonatal brain culture to enrich for brain precursors with properties close to those present at birth. Immunopurification of PSA-NCAM+ cells resulted in selection of $10-30 \%$ of the cells shaken off from the neonatal brain cultures.

Table 1 summarizes the phenotype of the immunopanned cells. PSA-NCAM + cells constitute a mean of $87 \%$ of this population (Fig. 1A). This percentage is likely to be an underestimate because trypsinization of cells from the panning plates may cleave off membrane NCAM molecules bearing PSA, and/or PSA epitopes may be masked by the secondary antibody (used during panning) and not be available for detection by the fluorescent secondary antibody. The great majority of PSA-NCAM+ cells were positive for the intermediate filament protein nestin, which is expressed in rat embryonic neural precursors (Hockfield and McKay, 1985). Most immunopurified cells expressed PDGFR $\alpha$, which was initially described as specific for 0-2A progenitors (Pringle et al., 1992; Nishiyama et al., 1996) but has also been detected recently on uncommitted neural precursors (Williams et al., 1997). A mean of $15 \%$ of the cells expressed the O-2A progenitor cell marker GD3 (Fig. 1B), $\sim 12 \%$ expressed the

$\leftarrow$

2 weeks in FGF2 and differentiated for $5 \mathrm{~d}$. In $\mathrm{D}$, many GFAP+ astrocytes (blue) have migrated out of the central cluster $(\mathrm{Cl})$ and are surrounded by O4+ oligodendrocyte lineage cells (red) but no neurons (photomontage of 4 fields). E, After triple labeling for A2B5/GD3 and GFAP, another cluster $(\mathrm{Cl})$ shows many GFAP + (blue) type 1 astrocytes radiating from its center; some of these are type 2 astrocytes because they also stain with A2B5 $\mathrm{Ab}$ (red). GD3+ processes ( green) of O-2A progenitors are radiating out of the cluster. $F$, PSA immunopanned neural precursors grown in EGF and differentiated for $7 \mathrm{~d}$ also show glial populations of astrocytes (blue) and oligodendrocytes $(\mathrm{red})$ in the outgrowth. No neurons were formed by this cluster. $G$, In contrast, PSA-NCAM-negative (unpanned cells) neural precursors grown in EGF give rise to neurons (MAP2, green), astrocytes (blue), or oligodendrocytes (red) (see Fig. 6). Similar results were obtained with striatal neural stem cells (see Fig. 7). Magnification: $A, 530 \times ; B, 415 \times ; C, 365 \times$; $D, 125 \times ; E, 210 \times ; F, 190 \times ; G, 360 \times$. 
Figure 4. T3 enhances the mitogenic effect of FGF2 on PSA-NCAM+ preprogenitor cells. $A$, MTT colorimetric assay for quantitation of cell growth in various conditions. One representative assay (out of 3 experiments) is shown with mean \pm SD of optical density measurement ( $n=4$ samples per condition). Neither T3 nor FGF2 alone stimulated growth but the combination of the two factors led to enhanced proliferation. PDGF induced similar growth as FGF2. $B$, TUNEL assay for apoptosis after $3 \mathrm{~d}$ in culture in various conditions. Values are the mean \pm SEM of three experiments. T3 alone did not increase the percentage of TUNEL negative cells (i.e., living cells) as compared with control conditions. FGF2 alone caused a small (statistically nonsignificant) increase in survival. The combination of the two factors significantly increased survival ( $p=$ 0.075 as compared with FGF2 without T3). $C$, BrdU incorporation index after $3 \mathrm{~d}$ in culture. Values are mean \pm SEM of three experiments. T3 alone was not mitogenic on its own. FGF2 alone slightly increased BrdU incorporation. The combination of FGF2 and T3 significantly and synergistically enhanced BrdU incorporation $(p=0.02$ as compared with FGF2 without T3). $D$, Quantitation of MTT + cell clusters observed in the dish after 1 week in culture. Values are the mean \pm SEM of three experiments. Again, T3 did not induce cell cluster formation; FGF2 alone showed only a small increase in their number, but the combination of the factors caused a large increase in the number of cell clusters that were formed ( $p=0.0003$ as compared with FGF2 without T3).

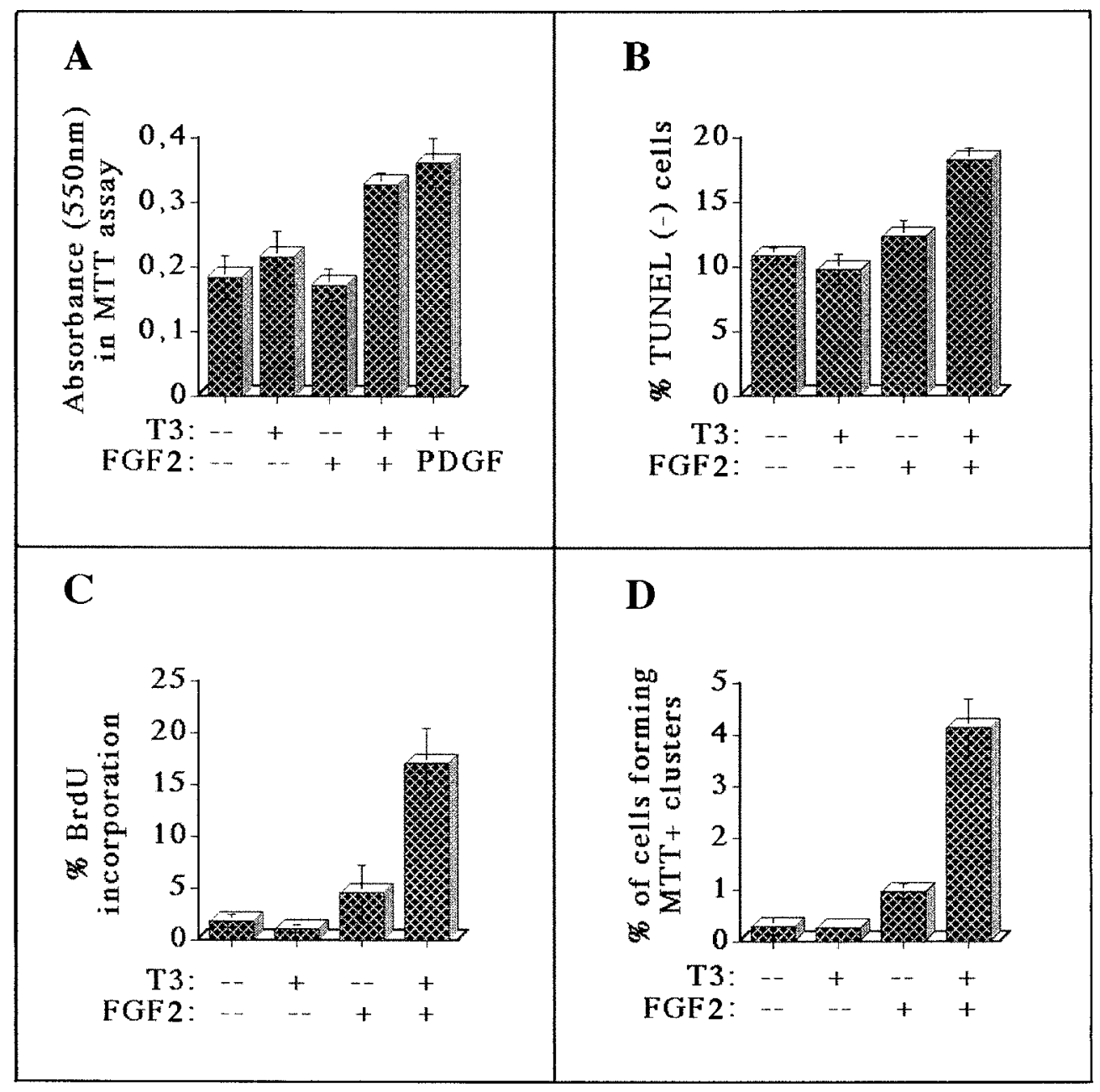

ganglioside identified by the A2B5 antibody, and $\sim 8 \%$ of the cells were positive with the $\mathrm{O} 4 \mathrm{Ab}$. Thus most of these immunopurified PSA-NCAM+ cells were negative for oligodendrocyte progenitor markers. In addition, only a small percentage of cells belonged to other neural lineages, as detected by the astrocytic marker GFAP and the neuronal specific marker MAP2ab (clone AP20) (Table 1). Interestingly, most cells were stained by another MAP2 antibody (clone HM-2), which recognizes the a, b, and c isoforms of MAP2 (Fig. 1C). This suggests that the low molecular weight isoform MAP2c is expressed in these early precursor cells, in agreement with the recent observation on transient expression of MAP2c during oligodendrocyte development (Vouyiouklis and Brophy, 1996). In conclusion, the combined approach of shaking neonatal brain cultures followed by PSA antibody immunopanning resulted in high enrichment for cells with markers characteristic of early neural precursors [nestin,$+ \operatorname{PDGFR} \alpha+$ (Williams et al., 1997, Murray and Dubois-Dalcq, 1997)] and lacking O-2A progenitor markers. This population of cells will be referred to as pre-progenitors or PSA-NCAM+ cells.

\section{FGF2 promotes the growth of pre-progenitors into clusters}

PSA-NCAM + cells grew with FGF2 into progressively larger clusters when cells were plated on uncoated tissue culture dishes (Fig. 1D-G). Pre-progenitor clusters could be grown for $>2$ weeks with little migration and differentiation of cells outside of clusters. They were loosely attached to the surface and subsequently detached and floated like neurospheres (Weiss et al., 1996). Cell viability assay by MTT staining in situ showed that $33 \%$ of immunopanned cells were viable after $1 \mathrm{~d}$ and $11 \%$ were viable after $3 \mathrm{~d}$. Only a small fraction of these cells developed into clusters of MTT + cells $(\leq 5 \%)$, which contained essentially PSA$\mathrm{NCAM}+$, nestin + cells similar to those that we purified initially (Fig. 2A,B). Using the quantitative MTT assay, half-maximal proliferation of pre-progenitors was observed in the $1-10 \mathrm{ng} / \mathrm{ml}$ FGF2 range, with the dose-response curve reaching a plateau at $10 \mathrm{ng} / \mathrm{ml}$ (Fig. 3A). A similar dose-response curve was obtained for PDGF (data not shown). In situ MTT staining showed that 0.1 $\mathrm{ng} / \mathrm{ml}$ FGF2 could recruit the same percentage of cells to form clusters as higher FGF2 concentrations, probably through a survival effect (Fig. 3B). However, $10 \mathrm{ng} / \mathrm{ml} \mathrm{FGF2} \mathrm{induced} \mathrm{the}$ growth of larger clusters than $0.1 \mathrm{ng} / \mathrm{ml} \mathrm{FGF2} \mathrm{(Fig.} 3 C$ ), because of its effect on cell mitosis demonstrated by the BrdU labeling assay (Fig. 2A). Similarly, EGF (at $20 \mathrm{ng} / \mathrm{ml}$ ) induces growth of pre-progenitor clusters and DNA synthesis (Fig. $2 C$ ). The recruitment of cells to form clusters with EGF was identical to that described for FGF2 (data not shown).

\section{Pre-progenitor cell growth is dependent on thyroid hormone}

The MTT assay was used to quantify PSA-NCAM+ preprogenitor cell growth with or without T3 (Fig. $4 A$ ). The combi- 

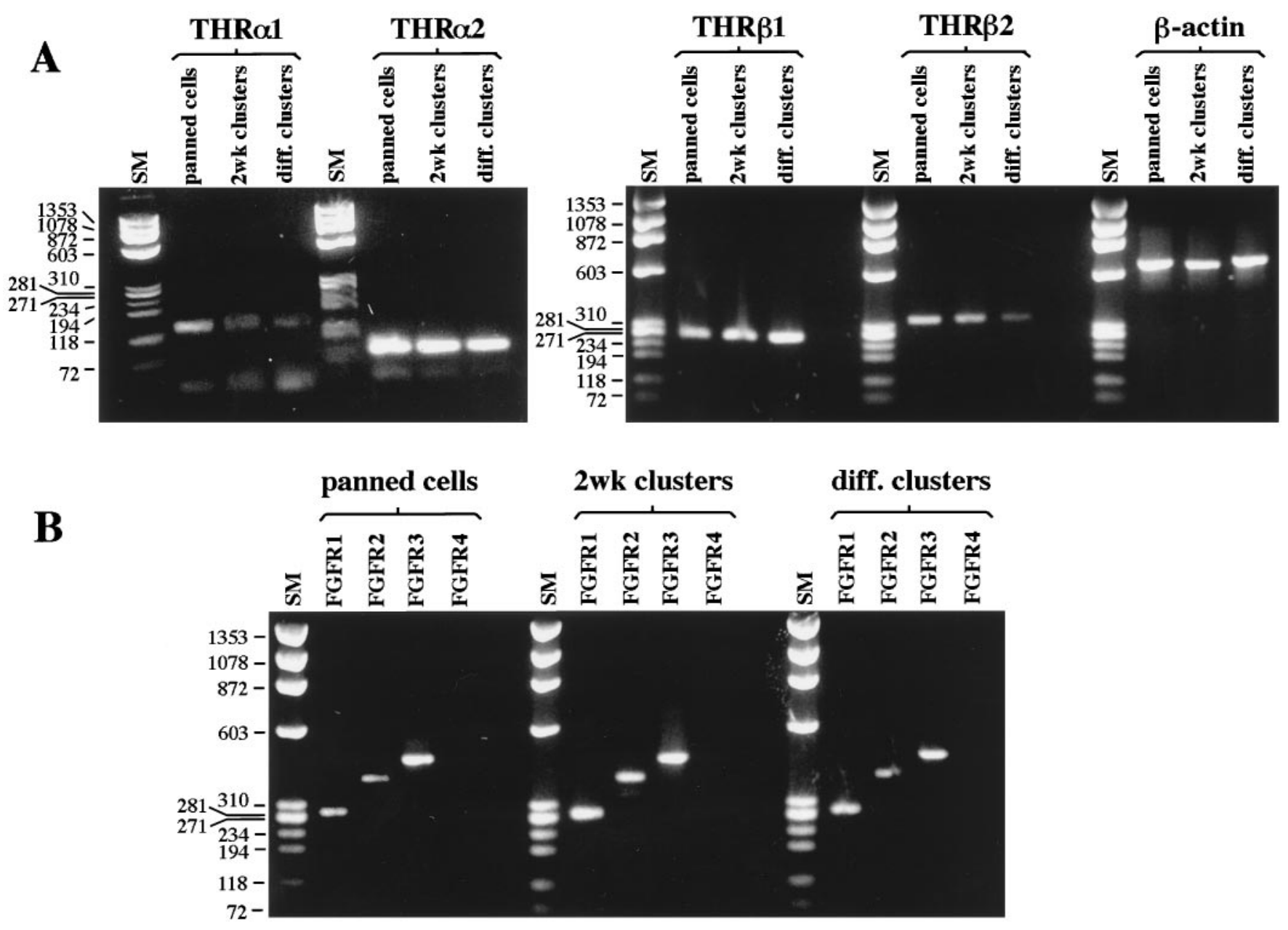

Figure 5. Expression of thyroid hormone receptors (THRs) and FGF receptors (FGFRs) in pre-progenitor cells at various stages of growth and differentiation. RNA was isolated from PSA-NCAM+ cells immediately after immunopanning (panned cells) from clusters of pre-progenitors that were grown for 2 weeks in the presence of FGF2 and T3 (2wk clusters) and from clusters that were grown as above and then differentiated for $5 \mathrm{~d}$ in the presence of T3 and absence of FGF2 (diff. clusters). A, RT-PCR for THR $\alpha 1,-\alpha 2,-\beta 1$, and - $\beta 2$, and $\beta$-actin. Equally strong signal intensities of $\beta$-actin were detected in the various RNA preparations as shown in the right panel in $A$. Both isoforms of THR $\alpha$ and THR $\beta$ are detected in these RNA preparations. THR $\alpha 1$ and THR $\beta 2$ signals were decreased in differentiating cell clusters compared with immunopanned cells. THR $\alpha 2$ and $-\beta 1$ signals are equally strong in all three cell preparations. $B$, RT-PCR for FGF receptors. FGFR1, FGFR2, and FGFR3 but not FGFR4 are expressed during the three developmental stages of pre-progenitor growth and development. SM, Molecular size marker ( $\phi$ x174 DNA digested with HaeIII).

nation of FGF2 and T3 led to maximal proliferation, whereas either one of the factors alone produced significantly lower growth. To determine how $\mathrm{T} 3$ affects the response of preprogenitors to FGF2, we assayed cell survival by the TUNEL method at $3 \mathrm{~d}$ in vitro, proliferation by BrdU incorporation between 3 and $4 \mathrm{~d}$, and the formation of MTT + clusters at $7 \mathrm{~d}$ (Fig. $4 B-D)$. In the absence of T3 and FGF2, 1 cell in 10 survived and $2 \%$ of total cells were in DNA synthesis after $3 \mathrm{~d}$ in vitro (Fig. $4 B, C)$, whereas only $\sim 1$ out of 330 of the initially plated cells had grown in clusters after $7 \mathrm{~d}$ (Fig. $4 D$ ). Addition of T3 to the culture medium did not significantly change any of these parameters. When only FGF2 was added, survival rate was slightly higher and 2.5-fold more cells were labeled with BrdU, but these differences were not statistically significant (Fig. 4B,C). However, a 3.3-fold increase over control was observed in the number of cells that developed into clusters at $7 \mathrm{~d}(p=0.02)$ (Fig. 3D). In cultures treated with both FGF2 and T3, survival was increased 1.7-fold over untreated control and 1.5-fold over cells treated with FGF2 alone $(p=0.0075)$ (Fig. $4 B)$. BrdU incorporation index was increased 3.8-fold over cells treated with FGF2 alone $(p=0.02)$ (Fig. $4 C$ ). Moreover, 4.3 times more cells formed clusters at $7 \mathrm{~d}$ as compared with cultures treated with FGF2 alone $(p=0.0003)$ (Fig. 4D). Cluster size after $3 \mathrm{~d}$ was four cells on average and approximately half of them incorporated BrdU. Therefore, the larger percentage of TUNEL (-) cells in the FGF2 + T3 condition probably is attributable mostly to enhanced proliferation.

The results suggest that $\mathrm{T} 3$ did not have a direct survival or mitogenic effect on PSA-NCAM+ pre-progenitor cells but could enhance the proliferative response of these cells to FGF2.

\section{Expression of thyroid hormone receptor and FGF receptor genes in pre-progenitor cells}

Because T3 enhanced the mitogenic response of pre-progenitors to FGF2, we examined whether there is a developmental stagespecific pattern of thyroid receptor subtype expression in our in vitro system. Thyroid hormone effects are mediated by products of two THR genes, each generating two isoforms by alternative splicing. THR $\alpha$ has been implicated in mitosis of neural precur- 


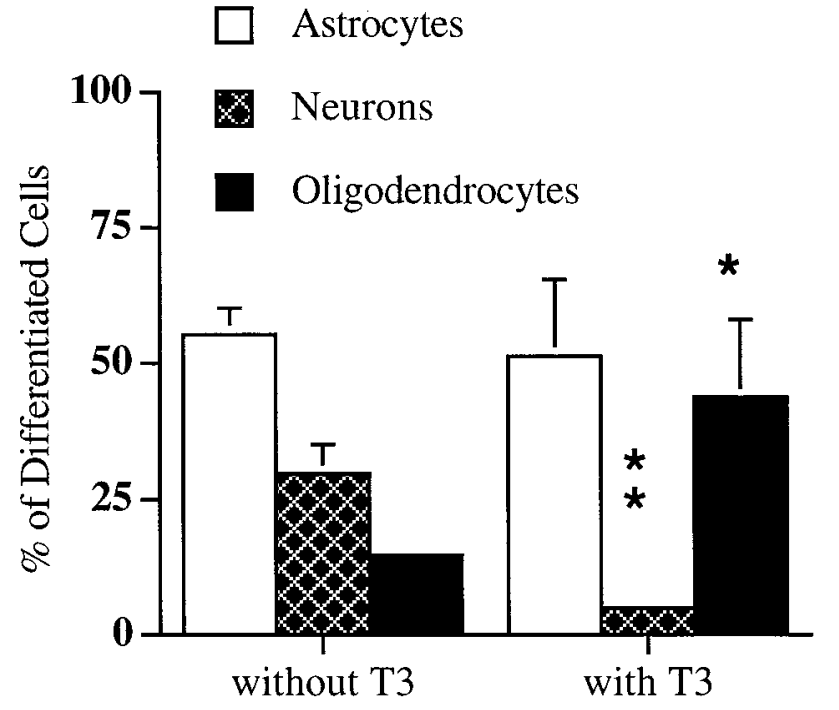

Figure 6. Striatal neural stem cells grown in FGF2 for $7 \mathrm{~d}$ were differentiated for $5 \mathrm{~d}$ without FGF2. Spheres cultured with or without T3 were analyzed after triple label for 04/MAP2/GFAP, and the ratio of the different cell types was calculated (see Materials and Methods). Fewer neurons formed $\left({ }^{* *} p<0.001\right)$ and more oligodendrocytes emerged $\left({ }^{*} p<\right.$ $0.05)$ in the presence of T3 than without. Three independent experiments were analyzed in the Student's $t$ test.

sors (Lezoualc'h et al., 1995), whereas changes in THR $\beta$ s have been correlated with oligodendrocyte maturation and with myelination (Forrest et al., 1991; Baas et al., 1994; Barres et al., 1994). THR expression was studied by RT-PCR in cells at three developmental stages: PSA-NCAM+ cells immediately after immunopanning and PSA-NCAM+ cell clusters grown for 2 weeks in FGF2 with T3 and in cell clusters that have been differentiating for $5 \mathrm{~d}$ on polyornithine-coated dishes without FGF2 (Fig. 5A). Both THR $\alpha$ and THR $\beta$ isoforms $(\alpha 1, \alpha 2, \beta 1, \beta 2)$ were detected in these three developmental stages. Using the signal intensity of $\beta$-actin as a semiquantitative reference for the amount of RNA, we found in two different RNA preparations that THR $\alpha 1$ and THR $\beta 2$ transcripts produced stronger signals in immunopanned cells than in differentiating cell clusters. Therefore, the expression of THRs $\alpha 1$ and THR $\beta 2$ may decrease when pre-progenitors stop to divide and differentiate. THR $\alpha 2$, which does not bind T3, and the THR $\beta 1$ isoforms showed similar signal intensity at the three developmental stages examined.

One way by which T3 can exert a permissive effect on FGF2 action is by inducing the expression of FGF receptors (FGFRs) in the cells. We therefore examined whether the FGF- and T3induced growth of immunopanned cells into clusters is associated with changes in FGFR subtype expression. Using RT-PCR, we detected FGFR1, FGFR2, and FGFR3 but not FGFR4 in the three developmental stages of our culture system (Fig. 5B). As a positive control, FGFR4 transcripts were detected in RNA from rat lung (data not shown). The results did not show qualitative or quantitative significant differences in FGFR expression between pre-progenitors before and after they were grown with FGF2 and T3. Thus T3 did not selectively enhance transcripts of one type of FGFR nor did it seem to increase their mRNA expression level in cell clusters.

In recent experiments, the Erb B1 receptor for EGF was also detected by RT-PCR in isolated PSA-NCAM clusters, after 2 weeks of growth and in differentiating clusters (data not shown).

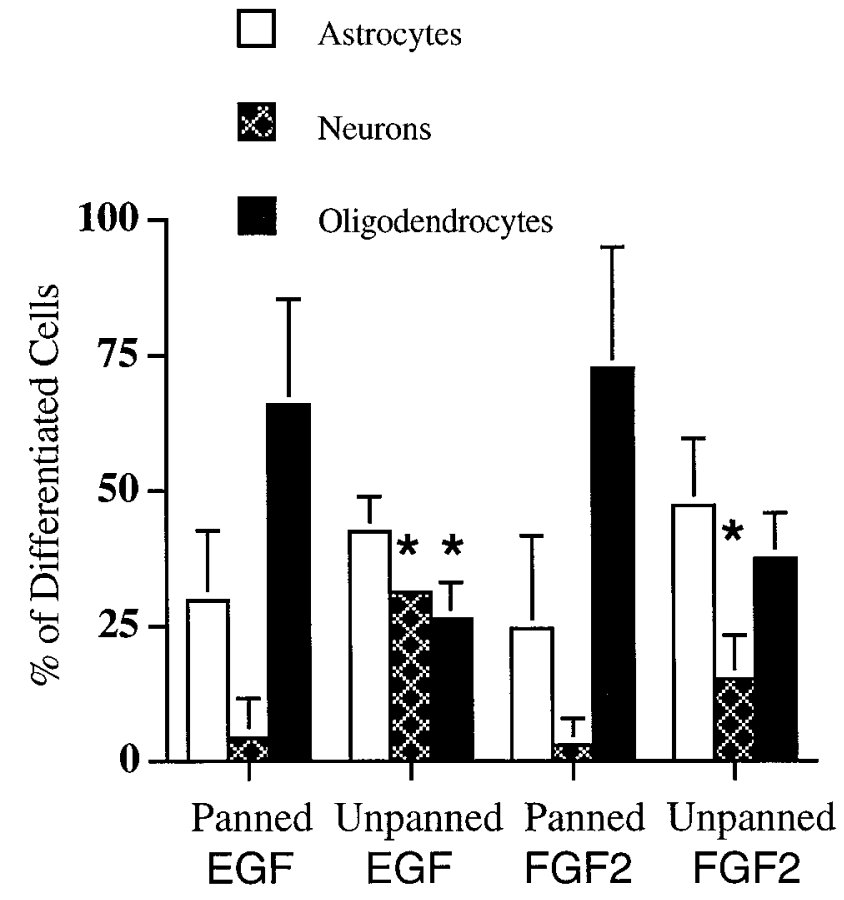

Figure 7. Cell fate of PSA-NCAM-positive and -negative neonatal precursors grown in clusters/spheres with EGF or FGF2 and analyzed as in Figure 6. With each of these growth factors, PSA-NCAM immunopanned cells (panned) gave rise mostly to oligodendrocytes and astrocytes, whereas PSA-NCAM negative cells (unpanned) gave rise to the three CNS cell types. Within each growth factor group, the ratio of neuronal cells was significantly higher in unpanned cells $\left({ }^{*} p<0.05\right)$. In the EGF group, the ratio of oligodendrocytes was significantly lower in unpanned than panned cells $(* p<0.05)$, whereas this significance was not reached in the FGF2 group (also see Fig. 6). Three independent experiments were analyzed in the Student's $t$ test.

\section{The fate of PSA-NCAM + cells differs from that of neural stem cells and of PSA-NCAM - cells}

We then investigated the fate of clusters/spheres of preprogenitors after adhesion and compared it with the fate of neural stem cells isolated from newborn rat striata and grown in neurospheres with FGF2 or EGF (Weiss et al., 1996). In all cases, spheres were grown in growth factors for 1-2 weeks and then transferred onto a dish or coverslip coated with polyornithine in the same medium without growth factors. Within a few hours, cells migrated out of the clusters/spheres and grew processes, often showing a bipolar shape. After $5 \mathrm{~d}$, there were many differentiated cells in the outgrow th that were analyzed by triplelabel immunofluorescence with O4, GFAP, and MAP2 antibodies.

The great majority of pre-progenitor clusters gave rise to oligodendrocyte lineage $\mathrm{O} 4+$ cells as well as GFAP + astrocytes. Usually, astrocytic processes radiated out from the core of the cluster, and multipolar $\mathrm{O} 4+$ cells of the oligodendrocyte lineage and GFAP + astrocytes surrounded the clusters (Fig. 2D). Triple labeling with GD3+, A2B5, and GFAP antibodies showed the presence of bipolar GD3 + 0-2A progenitors in the outgrowth, where GFAP+/A2B5 - type 1 and occasionally GFAP+/A2B5+ type 2 astrocytes could be found as well. Type 2 astrocytes were found in $6-19 \%$ of the clusters in three experiments (Fig. 2E). Only rarely were MAP2+ neurons encountered in these cultures. PSA-NCAM+ pre-progenitors that were expanded with EGF 


\begin{tabular}{|c|c|c|c|}
\hline & Embryonic Neural Stem Cells & Neonatal Brain Pre-progenitors & CNS O-2A Progenitors \\
\hline $\begin{array}{l}\text { Shape in phase } \\
\text { microscope }\end{array}$ & $\begin{array}{l}\text { Flat or bipolar, can grow } \\
\text { in spheres }\end{array}$ & $\begin{array}{l}\text { Small round, growing } \\
\text { in clusters/spheres }\end{array}$ & Bipolar with long processes and motile \\
\hline Antigenic phenotype & Nestin + & $\begin{array}{l}\text { PSA-NCAM and } \\
\text { nestin + A2B5-, GD3- }\end{array}$ & $\begin{array}{l}\text { Progressive loss of PSA-NCAM } \\
\text { and nestin, but A2B5+, GD3+ }\end{array}$ \\
\hline $\begin{array}{l}\text { Mitogenic growth } \\
\text { factors }(\mathrm{GF})\end{array}$ & FGF2, $\mathrm{EGF}^{a}$ & FGF2, PDGF, EGF & FGF2, PDGF, NT3, IGF-1 \\
\hline $\begin{array}{l}\text { Thyroid hormone } \\
\text { effects }\end{array}$ & Can induce an OL fate ${ }^{b}$ & $\begin{array}{l}\text { Enhances FGF2-mediated } \\
\text { growth }\end{array}$ & $\begin{array}{l}\text { Limits proliferation and triggers } \\
\text { myelin gene expression }{ }^{c}\end{array}$ \\
\hline $\begin{array}{l}\text { Differentiation } \\
\text { potential }\end{array}$ & $\begin{array}{l}\text { Neurons, astrocytes, } \\
\text { and OL }\end{array}$ & OL and astrocytes & OL and type 2 astrocytes \\
\hline
\end{tabular}

OL, Oligodendrocyte.

${ }^{a}$ Weiss et al., 1996.

${ }^{b}$ Johe et al., 1996.

${ }^{c}$ Barres et al., 1994; Hudson et al., 1996.

generated a similar glial population after differentiation (Fig. $2 F$ ). The fate of pre-progenitors grown without T3 could not be studied because of their inability to expand in the absence of this hormone.

We then examined the fate of neural stem cell spheres grown with FGF2 and T3 like the pre-progenitors and found that after adhesion these spheres generated mostly astrocytes $(51 \%)$ and oligodendrocytes $(44 \%)$, whereas only $5 \%$ neurons were observed (Fig. 6). To determine the influence of growth factors and T3 on stem cell fate, we also analyzed which CNS cells were generated by similar neurospheres grown in FGF2 but in the absence of T3 (Fig. 6). In contrast to PSA-NCAM+ cells, neural stem cell growth did not require T3. In the absence of this hormone, adherent neurospheres generated $30 \%$ neurons, whereas the proportion of oligodendrocytes fell to $15 \%$ (Fig. 6). Neural stem cells grown in EGF, the mitogen most often used to grow neural stem cells in spheres (Weiss et al., 1996), also generated the three CNS cell types in the absence of T3 (data not shown). Thus T3 added to neural stem cells during their growth and differentiation caused a significant increase in the percentage of oligodendrocytes, mainly at the expense of neurons. This correlates with the observation that T3 can instruct multipotential neural stem cells to become mostly oligodendrocytes (Johe et al., 1996). Alternatively, T3 could favor the survival of pre-progenitors of oligodendrocytes generated by stem cells, whereas neuronal progenitors would not depend on T3 for their survival. It was also shown that FGF2 at $10 \mathrm{ng} / \mathrm{ml}$ can drive stem cells into a mostly oligodendrocyte fate (Qian et al., 1997). Thus one interpretation of our data would be that neural stem cells as well as pre-progenitors could adopt a mostly glial fate when expanded with FGF2 and T3.

We therefore compared the fate of PSA-NCAM-positive cells with that of PSA-NCAM-negative neonatal neural precursors, which we predicted would contain the neonatal stem cell population. To this goal, we purified PSA-NCAM+ cells by immunopanning (as above) and collected the cells nonadhering to the anti-PSA antibody-coated plates (called "unpanned") before growing both populations in EGF or FGF2 on nonadherent substrates. Because growth of pre-progenitors is dependent on T3, this hormone was added to all growth media. We then analyzed the fate of these two distinct cell populations by triple immunolabeling $5 \mathrm{~d}$ after adhesion and withdrawal of the mitogen. We observed a striking difference between the fate of PSA-
NCAM antibody panned and unpanned precursors independent of the mitogen used (Fig. 7). PSA-NCAM-negative cells were multipotential and could generate neurons, whereas PSA$\mathrm{NCAM}+$ precursors generated mainly glia (Fig. $2 F, G)$. Interestingly, the ratio of the three CNS cell types varies between EGF and FGF2 spheres grown from unpanned cells. In FGF2-grown spheres, the ratio of neurons was two times lower than in those grown in EGF, as also observed with neural stem cells (Fig. 6). In both cases, the increase in the ratio of oligodendrocytes was proportional to the decrease in the ratio of neuronal cells. Taken together these results suggest that under our experimental conditions, unpanned PSA-NCAM-negative cells correspond mostly to multipotential neural stem cells and that T3 and FGF2 may promote a glial fate in these neonatal stem cells. In contrast, PSA-NCAM + cells are restricted to a glial fate independent of the mitogen used to grow them.

\section{DISCUSSION}

We describe here the growth and fate of neonatal brain PSA$\mathrm{NCAM}+$ precursors grown in clusters/spheres that differentiate after adhesion to a substrate. The antigenic profile of these precursors closely resembles that of pre-progenitors known to generate O-2A progenitors (Grinspan et al., 1990, 1995). Such neonatal pre-progenitors represent a transition stage between neural stem cells and O-2A progenitors (Table 2). Features resembling those of neural stem cells are the expression of nestin, their dependence on FGF2 or EGF for proliferation, and their ability to grow on nonadherent surface into clusters that eventually float like stem cell neurospheres (Vescovi et al., 1993; Gritti et al., 1996; Johe et al., 1996). Yet PSA-NCAM+ neural precursors differ from PSA-NCAM-negative multipotential neural stem cells because they have a more restricted potentiality, generating mostly cells of the oligodendrocyte and astrocyte lineages. Growth factors and thyroid hormone can influence cell fate in both types of neonatal precursors: T3 is not required for the growth of true multipotential neural stem cells but may instruct these to become glia (Johe et al., 1996; this study). In addition, T3 and FGF2 act together to promote the development of cells of the astrocyte and oligodendrocyte lineage from neural stem cells. This situation is different from that of PSA-NCAM + neural precursors, which require $\mathrm{T} 3$ to enhance their growth and generate mostly astrocytes and oligodendrocytes independent of the 
factor used to grow them. Thus appearance of PSA-NCAM at the surface of neonatal brain precursors coincides with their restriction to a mostly glial fate.

Thyroid hormone can act at multiple stages of oligodendrocyte development. T3 enhancement of growth factor-driven proliferation of PSA-NCAM+ neonatal precursor differs from its effects on $\mathrm{O}-2 \mathrm{~A}$ progenitors from optic nerve. In this case, $\mathrm{T} 3$ limits the proliferative potential of O-2A progenitors in the continued presence of mitogenic growth factors (Barres et al., 1994; Baas et al., 1997), whereas in the absence of T3, fewer oligodendrocytes develop in these cultures (Ahlgren et al., 1997). Such distinct T3 effects might be mediated by different THRs. THR $\alpha$ isoforms are expressed early in brain development, whereas THR $\beta$ appears later and in a more restricted pattern (Mellström et al., 1991; Bradley et al., 1992). THR $\alpha$ (most precisely the $\alpha 1$ isoform) but not $\mathrm{THR} \beta$ was shown to mediate mitogenic effect on chick neuroblasts (Lezoualc'h et al., 1995). The RT-PCR data shown here, although not quantitative, suggest that THR $\alpha 1$ expression was strongest during the proliferative stage of pre-progenitor growth and decreased on differentiation. In the rat brain, THR $\beta 1$ mRNA sharply increases between E19 and postnatal day 10, suggesting a correlation with the initiation of myelination (Strait et al., 1990; Forrest et al., 1991; Mellström et al., 1991). THR $\beta 1$ expression is induced on differentiation of oligodendrocytes (Baas et al., 1994; Besnard et al., 1994), whereas THR $\beta 2$ isoform is detected in O-2A progenitors but not in mature oligodendrocytes (Barres et al., 1994). Similarly, our data suggest that THR $\beta 2$ expression may be downregulated after pre-progenitor clusters have differentiated. It is also possible that T3 may induce synthesis of growth factors such as PDGF or neurotrophins in neural precursor clusters/spheres (Alvarez-Dolado et al., 1994; Iglesias et al., 1995; Neveu and Arenas, 1996). Thus, in our system, T3 could exert an indirect trophic effect by inducing the synthesis of specific growth factors by pre-progenitor cells. Preliminary RT-PCR analysis detected PDGF-A and PDGF-B but not NGF or NT3 expression in growing clusters (data not shown).

The ability to respond to FGF2 appears to be common to multipotential neural stem cells, pre-progenitors as well as O-2A progenitors, which are committed to an oligodendrocyte fate (Table 2). Accordingly, we found that PSA-NCAM+ preprogenitors express FGFR1, FGFR2, and FGFR3 but not FGFR4, just as multipotential cortical stem cells do (Qian et al., 1997). It is possible that T3 may enhance FGF2 effects by induction or enhancement of FGFRs expression. Complex regulation of FGFRs in the oligodendrocyte lineage has been shown recently (Bansal et al., 1996). We did not find major changes in FGFRs transcripts levels in pre-progenitors in expansion compared with those in differentiation after adhesion, but this does not rule out changes in FGFR protein levels. PSA-NCAM+ precursors also respond to EGF and express its receptor, whereas EGF is not a known mitogen for O-2A progenitors.

Growth of precursors in spheres can be obtained even at a stage when these cells are committed to an oligodendrocyte fate. $\mathrm{GD} 3$ + rat oligodendrocyte progenitors were propagated on nonadherent substrate in the form of "oligospheres," particularly with conditioned medium (CM) of a neuroblastoma cell line, B104 (Avellana-Adalid et al., 1996). In addition, EGF-grown neural spheres from the neonatal brain can be progressively transformed into oligospheres by growth in B104 CM (Zang et al., 1997). When dissociated and plated on adhesive substrate, these oligospheres generated typical O-2A progenitors evolving into oligodendrocytes or type 2 astrocytes depending on serum concentra- tion. Recently, the presence of PSA-NCAM + pre-progenitors was demonstrated in the center of mouse oligospheres (Baronvan Evercooren et al., 1997). In our system, the growth of single PSA-NCAM immunoselected cells on nonadherent substrate with FGF2 (or EGF) and T3 resulted in highly homogenous populations of pre-progenitors in the floating cell clusters. When grafted, PSA-NCAM+ precursors are able to produce a remarkable amount of myelin around naked axons in a focal demyelinated lesion in adult rats (Keirstead et al., 1998).

The PSA-NCAM+ neural precursors characterized here in vitro appear to correspond to the bipotential glial precursors described in the neonatal rat brain (Goldman,1996). Neonatal subventricular zone precursor cells can produce both astrocytes and oligodendrocytes when they migrate into the gray matter in vivo, suggesting the existence of a common glial precursor for both cell types (Levison and Goldman, 1993). Pre-progenitors are likely to originate from SVZ because these cells can be isolated from deep cerebral white matter but not from optic nerve (Grinspan et al., 1990). The mostly glial fate of pre-progenitors may be caused by specific signals in the neonatal brain environment that also trigger the expression of PSA-NCAM.

Glial-restricted precursors can also be derived from embryonic day (E) 10.5 spinal cord (Rao and Mayer-Proschel, 1997). These precursors were labeled by the anti-ganglioside antibody A2B5 and gave rise to astrocytes and oligodendrocytes as already suggested by an earlier study (Fok-Seang and Miller, 1994). In the neonatal brain, this antibody rarely stained immunopanned PSA$\mathrm{NCAM}+$ precursors (Table 1). Clearly, the appearance of specific surface molecules may vary with the CNS region and the age from which such precursors are isolated. Interestingly, lineagerestricted neuronal precursors were also found to derive from multipotential neural stem cells isolated from the E13.5 spinal cord (Mayer-Proschel et al., 1997). These precursors could be distinguished from neural stem cells by the emergence of PSANCAM. This is in agreement with the proposal that embryonic NCAM is not expressed on neural stem cells but emerges when cells move along a particular lineage and/or restrict their fate (Kiss and Rougon, 1997). In the neonatal rat brain, we show here that emergence of PSA-NCAM coincides also with a restricted fate, but at this time of CNS development when neurons are already in place, the fate is mostly restricted to glial lineages.

In conclusion, we have first demonstrated that PSA-NCAM+ pre-progenitor cells isolated from the neonatal brain can expand in response to FGF2 and that $\mathrm{T} 3$ has a permissive effect on this FGF2-stimulated growth. We then showed that PSA-NCAM precursors differ from true multipotential stem cells in that they mostly generate astrocytes and oligodendrocytes and behave like bipotential glial progenitors. Such an in vitro system therefore should allow the study of the molecular basis of decisions toward the astrocyte and oligodendrocyte fate.

\section{REFERENCES}

Ahlgren SC, Wallace H, Bishop J, Neophytou C, Raff MC (1997) Effects of thyroid hormone on embryonic oligodendrocyte precursor cell development in vivo and in vitro. Mol Cell Neurosci 9:420-432.

Almazan G, Honegger P, Matthieu J-M (1985) Triidothyronine stimulation of oligodendroglial differentiation and myelination. Dev Neurosci 7:45-54.

Alvarez-Dolado M, Iglesias T, Rodriguez-Pena A, Bernal J, Munoz A (1994) Expression of neurotrophins and the trk family of neurotrophin receptors in normal and hypothyroid rat brain. Brain Res Mol Brain Res 27:249-257.

Armstrong RC, Harvath L, Dubois-Dalcq ME (1990) Type 1 astrocytes 
and oligodendrocyte-type 2 astrocyte glial progenitors migrate toward distinct molecules. J Neurosci Res 27:400-407.

Avellana-Adalid V, Nait-Oumesmar B, Lachapelle F, Baron-Van Evercooren A (1996) Expansion of rat oligodendrocyte progenitors into proliferative "oligospheres" that retain differential potential. J Neurosci Res 45:558-570.

Baas D, Bourbeau D, Carre JL, Sarlieve LL, Dussault JH, Puymirat J (1994) Expression of $\alpha$ and $\beta$ thyroid receptors during oligodendrocyte differentiation. NeuroReport 5:1805-1808.

Baas D, Bourbeau D, Sarlieve LL, Ittel ME, Dussault JH, Puymirat J (1997) Oligodendrocyte maturation and progenitor cell proliferation are independently regulated by thyroid hormone. Glia 19:324-332.

Bansal R, Warrington AE, Gard AL, Ranscht B, Pfeiffer SE (1989) Multiple and novel specificities of monoclonal antibodies O1, O4, and $\mathrm{R}-\mathrm{mAb}$ used in the analysis of oligodendrocyte development. J Neurosci Res 24:548-557.

Bansal R, Kumar M, Murray K, Morrison RS, Pfeiffer SE (1996) Regulation of FGF receptors in the oligodendrocyte lineage. Mol Cell Neurosci 7:263-275.

Baron-van Evercooren A, Avellana-Adalid A, Vitry S, Hardy R, Peterson A, La Chapelle F (1997) Mouse oligospheres: from preprogenitors to mature oligodendrocytes. J Neurochem 69[Suppl]:S230.

Barres BA, Lazar MA, Raff MC (1994) A novel role for thyroid hormone, glucocorticoids and retinoic acid in timing oligodendrocyte development. Development 120:1097-1108.

Besnard F, Luo M, Miehe M, Dussault JH, Puymirat J, Sarlieve LL (1994) Transient expression of 3,5,3'-triiodothyronine nuclear receptors in rat oligodendrocytes: in vivo and in vitro immunocytochemical studies. J Neurosci Res 37:313-323.

Bogler O, Wren D, Barnett SC, Land H, Noble M (1990) Cooperation between two growth factors promotes extended self-renewal and inhibits differentiation of oligodendrocyte type-2-astrocyte (O-2A) progenitor cells. Proc Natl Acad Sci USA 87:6368-6372.

Bradley DJ, Towle HC, Young III WS (1992) Spatial and temporal expression of $\alpha$ and $\beta$ thyroid hormone receptor mRNA, including the $\beta 2$ subtype, in the developing mammalian nervous system. J Neurosci 12:2288-2302.

Davis AA, Temple S (1994) A self-renewing multipotential stem cell in embryonic rat cerebral cortex. Nature 372:263-266.

Eisenbarth GS, Walsh FS, Nirenburg M (1979) Monoclonal antibody to a plasma membrane antigen of neurons. Proc Natl Acad Sci USA 76:4913-4917.

Farsetti A, Mitsuhashi T, Desvergne B, Robbins J, Nikodem VM (1991) Molecular basis of thyroid hormone regulation of myelin basic protein gene expression in rodent brain. J Biol Chem 266:23226-23232.

Fok-Seang J, Miller R (1994) Distribution and differentiation of A2B5 ${ }^{+}$ glial precursors in the developing rat spinal cord. J Neurosci Res 37:219-235.

Forrest D, Hallböök F, Persson H, Vennström B (1991) Distinct functions for thyroid hormone receptors alpha and beta in brain development indicated by differential expression of receptor genes. EMBO J 10:269-275.

Gavrieli Y, Sherman Y, Ben-Sasson SA (1992) Identification of programmed cell death in situ via specific labeling of nuclear DNA fragmentation. J Cell Biol 119:493-501.

Goldman JE (1996) Developmental origins of astrocytes. In: Glial cell development (Jessen KR, Richardson WD, eds), pp 31-51. Oxford: BIOS Scientific Publishers.

Goldman JE, Hirano M, Seyfried TN (1984) GD3 ganglioside is a glycolipid characteristic of immature neuroectodermal cells. J Neuroimmunol 7:179-192.

Grinspan JB, Franceschini B (1995) Platelet-derived growth factor is a survival factor for PSA-NCAM+ oligodendrocyte pre-progenitor cells. J Neurosci Res 41:540-551.

Grinspan JB, Stern JL, Pustilnik SM, Pleasure D (1990) Cerebral white matter contains PDGF-responsive precursors to O-2A cells. J Neurosci 10:1866-1873.

Gritti A, Parati EA, Cova L, Frolichsthal P, Galli R, Wanke E, Faravelli L, Morassutti DJ, Roisen F, Nickel DD, Vescovi AL (1996) Multipotential stem cells from the adult mouse brain proliferate and self-renew in response to basic fibroblast growth factor. J Neurosci 16:1091-1100.

Hardy R, Reynolds R (1991) Proliferation and differentiation potential of rat forebrain oligodendroglia progenitors both in-vitro and in-vivo. Development 111:1061-1070.
Hockfield S, McKay RDG (1985) Identification of major classes in the developing mammalian nervous system. J Neurosci 5:3310-3328.

Hudson LD, Ko N, Kim JG (1996) Control of myelin gene expression. In: Glial cell development: basic principles and clinical relevance (Jessen KR, Richardson WD, eds), pp 101-121. Oxford: BIOS Scientific Publishers.

Iglesias T, Llanos S, Lopez-Barahona M, Seliger B, Rodriguez-Pena A, Bernal J, Munoz A (1995) Induction of platelet-derived growth factor B/c-sis by the v-erbA oncogene in glial cells. Oncogene 10:1103-1110.

Johe K, Hazel TG, Muller T, Dugich-Djordjevic MM, McKay RDG (1996) Single factors direct the differentiation of stem cells from the fetal and adult central nervous system. Genes Dev 10:3129-3140.

Keirstead HS, Ben Hur T, Rogister B, Dubois-Dalcq M, Blakemore WF (1998) Remyelination by PSA-NCAM positive neural precursor cell clusters. Abstract for the 3rd European Meeting on Glial Cell Function in Health and Disease, Athens, May.

Kiss JF, Rougon G (1997) Cell biology of polysialic acid. Curr Opin Neurobiol 7:640-646.

Levison SW, Goldman JE (1993) Both oligodendrocytes and astrocytes develop from progenitors in the subventricular zone of postnatal rat forebrain. Neuron 10:201-212.

Lezoualc'h F, Seugnet I, Monnier AL, Ghysdael J, Behr JP, Demeneix BA (1995) Inhibition of neurogenic precursor proliferation by antisense $\alpha$ thyroid hormone receptor oligonucleotides. J Biol Chem 270:12100-12108.

Mayer-Proschel M, Kalyani AJ, Mujtaba T, Rao MS (1997) Isolation of lineage-restricted neuronal precursors from multipotent neuroepithelial stem cells. Neuron 19:773-785.

McKinnon RD, Matsui T, Dubois-Dalcq M, Aaronson SA (1990) FGF modulates the PDGF-driven pathway of oligodendrocyte development. Neuron 5:603-614.

Mellström B, Naranjo JR, Santos A, Gonzalez AM, Bernal J (1991) Independent expression of the alpha and beta c-erbA genes in developing rat brain. Mol Endocrinol 5:1339-1350.

Murray K, Dubois-Dalcq M (1997) Emergence of oligodendrocytes from human neural spheres. J Neurosci Res 50:146-156.

Neveu I, Arenas E (1996) Neurotrophins promote the survival and development of neurons in the cerebellum of hypothyroid rats in vivo. J Cell Biol 133:631-646.

Nishiyama A, Lin XH, Giese N, Heldin CH, Stallcup WB (1996) Colocalization of $\mathrm{NG} 2$ proteoglycan and $\mathrm{PDGF} \alpha$ receptor on $\mathrm{O} 2 \mathrm{~A}$ progenitor cells in the developing rat brain. J Neurosci Res 43:299-314

Pfeiffer SE, Warrington SE, Warrington AE, Bansal R (1994) The oligodendrocyte and its many cellular processes. Trends Cell Biol 3:191-197.

Price J (1994) Glial cell lineage and development. Curr Opin Neurobiol 4:680-686.

Pringle N, Mudhar HS, Collarini EJ, Richardson WD (1992) PDGF receptors in the CNS: during late neurogenesis, expression of PDGF alpha receptors appears to be restricted to glial cells of the oligodendrocyte lineage. Development 115:535-551.

Qian X, Davis AA, Goderies SK, Temple S (1997) FGF2 concentration regulates the generation of neurons and glia from multipotent cortical stem cells. Neuron 18:81-93.

Raff MC (1989) Glial cell diversification in the rat optic nerve. Science 243:1450-1455.

Raff MC, Miller RH, Noble MD (1983) A glial progenitor cell that develops in vitro into an astrocyte or an oligodendrocyte depending on the culture medium. Nature 303:390-396.

Raff MC, Lillien LE, Richardson WD, Burne JF, Noble MD (1988) Platelet derived growth factor from astrocytes drives the clock that limits oligodendrocyte development in culture. Nature 333:562-565.

Rao MS, Mayer-Proschel M (1997) Glial restricted precursors are derived from multipotent neuroepithelial stem cells. Dev Biol 188:48-63.

Reynolds BA, Weiss S (1992) Generation of neurons and astrocytes from isolated cells of the adult mammalian central nervous system. Science 255:1707-1710.

Richardson WD, Pringle N, Mosley MJ, Westermark B, Dubois-Dalcq M (1988) A role for platelet derived growth factor in normal gliogenesis in the central nervous system. Cell 53:309-319.

Rougon G, Dubois C, Buckley N, Magnani JL, Zollinger W (1986) A mouse monoclonal antibody against meningococcus group B polysaccharides distinguishes embryonic form from adult N-CAM. J Cell Biol 103:2429-2437. 
Sommer I, Schachner M (1981) Monoclonal antibodies (O1 to O4) to oligodendrocyte cell surface: an immunocytological study in the central nervous system. Dev Biol 83:311-327.

Strait KA, Schwartz HL, Perez-Castillo A, Oppenheimer JH (1990) Relationship of c-erbA mRNA content to tissue triiodothyronine nuclear binding capacity and function in developing and adult rats. J Biol Chem 265:10514-10521.

Vescovi AL, Reynolds BA, Fraser DD, Weiss S (1993) bFGF regulates the proliferative fate of unipotent (neuronal) and bipotent (neuronal/ astroglial) EGF-generated CNS progenitor cells. Neuron 11:951-966.

Vouyiouklis DA, Brophy PJ (1996) Microtubule-associated proteins in developing oligodendrocytes: transient expression of a MAP2c isoform in oligodendrocyte precursors. J Neurosci Res 42:803-817.
Weiss SM, Reynolds BA, Vescovi AL, Morshead C, Craig CG, Van der Koy D (1996) Is there a neural stem cell in the mammalian forebrain? Trends Neurosci 19:387-393.

Williams BP, Read J, Price J (1991) The generation of neurons and oligodendrocytes from a common precursor cell. Neuron 7:685-693.

Williams BP, Park JK, Alberta JA, Muhlebach SG, Huang GY, Roberts TM, Stiles CD (1997) A PDGF-regulated immediate early gene response initiates neuronal differentiation in ventricular zone progenitor cells. Neuron 18:553-562.

Zang SC, Lundberg C, Lipsitz D, Duncan ID (1998) Characterization and transplantation of rat oligodendrocyte progenitors derived from EGF-responsive subventricular progenitor cells. J Neurocytol, in press. 